\title{
Soluble interleukin-2 receptors: levels in leprosy, and during and after Type 1 (lepra) and Type 2 (ENL) reactions
}

\author{
V N SEHGAL, * $\$$ S N BHATTACHARYA, * Y SHAH, ${ }^{*}$ \\ V K SHARMA $\dagger \&$ C K GUPTA \\ Departments of Dermatology, Venereology and Leprology*, and \\ Microbiology†, Maulana Azad Medical College and associated \\ LNJPN and GB Pant Hospitals, New Delhi; Department of \\ Biostatistics $\ddagger$ V P Chest Institute, New Delhi, India
}

\section{Accepted for publication 15 March 1991}

\begin{abstract}
Summary Twenty-five patients with Type 1 (lepra) and Type 2 (ENL) reactions, were assayed for SIL-2R in serum-before and after treatment for their acute condition-and the results were compared with 10 normal healthy adults and 20 patients of leprosy per se. Classification of each subject into different leprosy groups, and into various types and subtypes of reactions, was done according to standard criteria, prior to inclusion into the study. Detailed statistical evaluation of the data revealed significantly higher levels of SIL-2R in all leprosy patients, as compared to normal controls, with higher levels in the multibacillary groups as compared to the paucibacillary group. SIL-2Rs appeared higher in Type 1 upgrading reaction than in other forms of reaction, though this was not statistically significant.

There was no significant change in levels following treatment and clinical remission.
\end{abstract}

\section{Introduction}

'Soluble' interleukin-2 receptors (SIL-2R), are part of the alpha polypeptide subunit $(55 \mathrm{Kd})$ with low affinity to IL-2, that are released from the cell membrane of activated immunocompetent cells under certain conditions, in vitro ${ }^{1}$ and in vivo. ${ }^{2,3}$ The role of this molecule in modulation of immune mechanisms is still unsettled although its 'potential' in down-regulating immune activation is well recognized. ${ }^{4}$ In addition to malignancies, ${ }^{3}$ AIDS $^{5}$ and autoimmune diseases, SIL-2R has been studied in leprosy patients per se with intriguing findings. ${ }^{6,7}$ The SIL-2R values were raised across the spectrum and did not vary significantly between the various clinical bacilliferous groups, while paucibacillary cases had significantly different values, falling somewhere between that of the normal healthy adults and the multibacillary clinical groups. However, in a few patients who were

$\S$ Correspondence: Prof V N Sehgal, A/6 Panchwati, Opp. Azadpur Subzi Mandi, Delhi 110 033, India. 
diagnosed to have 'reversal reaction', extremely high serum levels of the polypeptide were obtained. ${ }^{6}$

Since the immunopathogenic mechanisms in reactions of leprosy continue to be an enigma, it was thought worthwhile to investigate the levels of SIL-2R during reactions, and after clinical remission following the conventional treatment.

\section{Materials and methods}

\section{CLINICAL MATERIAL}

The study group consisted of 25 patients, of Type 1 (lepra) and Type 2 (ENL) reactions of leprosy. The primary diagnosis in each case was made by the criteria described by Ridley \& Jopling, ${ }^{8}$ with modifications as suggested by Sehgal. ${ }^{9,10}$ Accordingly the patients were grouped into borderline-tuberculoid (BT), borderline-borderline (BB), borderlinelepromatous (BL) and lepromatous (LL). Reactions were classified into either Type 1 (lepra) or Type 2 (ENL) reaction based on well-recognized clinical, bacteriological immunological and histopathological criteria. ${ }^{11}$ Patients having Type 1 (lepra) reaction were further subclassified into upgrading (reversal) or downgrading subtypes. ${ }^{11,12}$ Care was taken to differentiate the former from relapse and the latter from downgrading per $s e^{13}$ (Tables 1 and 2).

In addition to multidrug therapy, ${ }^{14}$ patients with Type 1 reaction were treated with chloroquine phosphate in tablet form ( $250 \mathrm{mg}$ IP), 1 tablet orally three times a day for 1 week, followed by 1 tablet twice daily for 1 week, and subsequently 1 tablet per day until the clinical subsidence of reaction. Patients with neurological symptoms were, in addition, given a tablet of prednisolone $20-40 \mathrm{mg}$ per day orally, in divided doses, along with suitable nursing and physiotherapy. ${ }^{15}$ Patients with Type 2 reaction on the other hand, were treated with prednisolone $40-80 \mathrm{mg}$ per day orally, in addition to augmented doses of clofazimine (150-300 mg per day in divided dosages) until clinical signs of reaction subsided. Corticosteroids were then gradually reduced, in a stepwise manner,

Table 1. Age in years of subjects/patients in various clinical groups as compared to that in normal healthy controls

\begin{tabular}{|c|c|c|c|c|c|}
\hline & \multirow[b]{3}{*}{ Leprosy groups } & \multirow{3}{*}{$\begin{array}{c}\text { No. of } \\
\text { subjects/patients }\end{array}$} & \multicolumn{3}{|c|}{ Age (in years) } \\
\hline & & & \multirow[b]{2}{*}{ Mean } & \multicolumn{2}{|c|}{$\begin{array}{l}95 \% \text { Confidence } \\
\text { limits }\end{array}$} \\
\hline & & & & Lower & Upper \\
\hline 1 & Normal healthy controls & 10 & $27 \cdot 7$ & $24 \cdot 5$ & $31 \cdot 4$ \\
\hline 2 & Normal BT controls & 10 & $28 \cdot 4$ & $23 \cdot 0$ & $35 \cdot 0$ \\
\hline 3 & Normal BL controls & 4 & $31 \cdot 5$ & $18 \cdot 3$ & $54 \cdot 2$ \\
\hline 4 & Normal LL controls & 6 & $32 \cdot 9$ & $23 \cdot 7$ & $45 \cdot 5$ \\
\hline 5 & BT upgrading (Type 1) & 4 & $39 \cdot 8$ & $23 \cdot 2$ & $68 \cdot 5$ \\
\hline 6 & BB upgrading (Type 1) & 2 & $42 \cdot 4$ & $27 \cdot 2$ & $66 \cdot 2$ \\
\hline 7 & BB downgrading (Type 1 ) & 3 & $26 \cdot 0$ & $12 \cdot 9$ & $52 \cdot 3$ \\
\hline 8 & BL downgrading (Type 1 ) & 5 & $37 \cdot 1$ & $34 \cdot 1$ & $40 \cdot 4$ \\
\hline 9 & BL Type II (ENL) & 2 & $35 \cdot 5$ & $18 \cdot 7$ & $67 \cdot 4$ \\
\hline 10 & LL Type II (ENL) & 9 & $33 \cdot 4$ & $26 \cdot 5$ & $42 \cdot 0$ \\
\hline
\end{tabular}


Table 2. Soluble interleukin-2 receptor in the various clinical groups, and before and after treatment for reactions

Unit-U/L

\begin{tabular}{|c|c|c|c|c|c|c|c|c|}
\hline & \multirow[b]{3}{*}{ Leprosy groups } & \multirow{3}{*}{$\begin{array}{c}\text { No. of } \\
\text { subjects/patients }\end{array}$} & \multicolumn{3}{|c|}{ Before treatment } & \multicolumn{3}{|c|}{ Af ter treatment } \\
\hline & & & \multirow[b]{2}{*}{ Mean } & \multicolumn{2}{|c|}{$\begin{array}{l}25 \% \text { Confidence } \\
\text { limits }\end{array}$} & \multirow[b]{2}{*}{ Mean } & \multicolumn{2}{|c|}{$\begin{array}{l}\text { 95\% Confidence } \\
\text { limits }\end{array}$} \\
\hline & & & & Lower & Upper & & Lower & Upper \\
\hline 1 & Normal healthy controls & 10 & 296 & 186 & 470 & - & - & - \\
\hline 2 & Normal BT controls & 10 & 482 & 295 & 786 & - & - & - \\
\hline 3 & Normal BL controls & 4 & 865 & 673 & 1111 & - & - & - \\
\hline 4 & Normal LL controls & 6 & 663 & 563 & 780 & - & & - \\
\hline 5 & BT upgrading (Type 1) & 4 & 897 & 318 & 2526 & 1119 & 652 & 1920 \\
\hline 6 & BB upgrading (Type 1) & 2 & 1243 & 806 & 1917 & 1332 & 812 & 2186 \\
\hline 7 & BB downgrading (Type 1 ) & 3 & 795 & 486 & 1302 & 608 & 256 & 1441 \\
\hline 8 & BL downgrading (Type 1) & 5 & 727 & 549 & 963 & 664 & 389 & 1131 \\
\hline 9 & BL Type II (ENL) & 2 & 587 & 507 & 679 & 724 & 484 & 1082 \\
\hline 10 & LL Type II (ENL) & 9 & 747 & 672 & 830 & 734 & 653 & 826 \\
\hline
\end{tabular}

and finally withdrawn, followed by a reduction in dosages of clofazimine to the standard MDT regime. ${ }^{14,15}$

Venous blood samples were collected before starting antireactional treatment and when clinical signs of reaction had abated. The sera was stored, after separation at room temperature, in glass containers at $-65^{\circ}$ to $-70^{\circ} \mathrm{C}$ (Forma Scientific deep-freeze).

Other investigations undertaken for all the patients included chest X-rays, haematological profile, blood sugar and urea, serum creatinine, liver enzymes, serum proteins acute phase treactants (alpha-1-antitrypsin and C-reactive protein) and lymphocyte adenosine deaminase activity.

\section{SIL-2R ESTIMATION}

SIL-2R estimation was performed using a commercially obtained ELISA kit (CELLFREE Interleukin-2 receptor test kit; CK1020; T-cell Sciences Inc., Cambridge, MA 02139, USA), from Hysel India Ltd. This kit included SIL-2R standards, anti-1 L-2R coating antibody, anti-IL-2R HRP conjugated antibody, sample diluent, substrate diluent, OPD (o-phenylene diamene) substrate, buffered hydrogen peroxide, buffer, blocking diluent and surfactant. The assay was carried out according to the manufacturers instructions after bringing the test samples gradually to room temperature. The optical readings were taken on an automatic ELISA reader (TITERTEK) at $490 \mathrm{~nm}$. A standard curve was plotted on a graph paper from the mean of readings obtained from the supplied standard solutions. The concentration of SIL-2R in the test samples were determined from the mean optical readings and the standard curve, and expressed as arbitrary units per $\mathrm{ml}$.

\section{CONTROLS}

Twenty patients with leprosy, derived from varous groups of leprosy, ${ }^{8-10}$ not having any 
clinical evidence of reaction, along with 10 normal healthy adult volunteers formed the controls for the study (Tables 1 and 2).

\section{STATISTICAL METHODS}

In view of the variability with respect of age and SIL-2R, observations were transformed to $\log$ values to achieve variance stability and normality. Analysis of variance (one way classification) was done to test for the significance of variation amongst the different clinical groups including normal healthy controls, and, finally, homoscedastic leprosy groups were pooled and subjected to weighted analysis of variance, as described by Welch. ${ }^{16}$ Individual and other sensible comparisons were done through linear contrasts. ${ }^{17}$ Significance of rise/fall after treatment was tested by ' $t$ ' test for paired samples.

\section{Results}

The age of all the patients, including normal healthy controls was $33 \pm 9$ (mean \pm SD) years, varying from 18 to 56 years. The age distribution of each of the clinical groups has also been given in Table 1. There was no evidence of significant $(p>0 \cdot 05)$ variation in age amongst the leprosy groups thus indicating that the groups were not significantly heterogeneous with respect to age.

Of the total patients studied $21 \cdot 8 \%$ were females. Few of the clinical groups did not have females. It was assumed that the low number of females in the other groups would have little effect on the study variables.

Table 2 gives the mean levels of SIL-2R in the age groups of leprosy, along with their $95 \%$ confidence limits. Mean SIL-2R level in BT patients (not in reaction) was observed to be higher, though not significantly, as compared to that in normal healthy controls $(p>0 \cdot 05)$. SIL-2R levels were significantly higher in the other clinical groups (normal BL controls, normal LL controls, and other reaction groups) as compared to the BT group and the normal healthy controls $(p<0 \cdot 05)$. SIL-2R values did not vary significantly before and after treatment in any of the test clinical groups.

On pooling together the data obtained from all patients with reactions into Type 1 upgrading group, Type 1 downgrading and Type 2 reaction groups, irrespective of primary disease classification, the mean SIL-2R level of Type 1 upgrading reaction appears higher than any of the other groups and is significant by the Students' ' $t$ ' test. However, on weighted analysis by the abovementioned method(s), no statistical significance could be established.

\section{Discussion}

The SIL-2R molecule, $10 \mathrm{Kd}$ less in size as compared to the alpha polypeptide subunit from which it is derived, ' has been studied and characterized. ${ }^{4}{ }^{18}$ Although the 'potential' of this molecule in immune regulation is well recognized, studies in different diseases have yet to prove its role in down-regulating IL-2 mediated immunological responses. Furthermore, in vitro studies to establish requirements for production of SIL-2 $\mathrm{R}^{19-22}$ and 
its affinity for IL-2, $4,23,24$ though supportive of the above hypothesis, have failed to establish the exact mechanism or role SIL-2R plays in the immune pathways.

Reactions in leprosy continues to be a poorly delineated phenomenon, perhaps unparalleled by any other infectious disease. While it is a well-recognized clinical entity, with well accepted immunological and histopathological criterias, ${ }^{12}$ the mechanis $m$ s are far from clear (why some patients develop reactions while others do not? What determines whether a patient with Type 1 reaction will upgrade or downgrade? What determines clinical subsidence of reaction?) and remain to be elucidated.

Though, from the results, no firm conclusion can be made regarding sex and age in reactions, indirect evidence that the clinical groups have an homogenous age representation, was obtained by the lack of significant age variation between the various groups.

SIL-2R values in the various test groups did not vary significantly from those obtained from the bacilliferous leprosy patients (without reaction), after detailed weighted analysis of the individual groups. BT patients (not having reaction) were all paucibacillary and had significantly lower SIL-2R $(p<0 \cdot 05)$. On pooling the data to form larger groups of patients with Type 1 (downgrading) or (upgrading), and Type 2 (ENL) reactions, Students' ' $t$ ' test revealed significantly higher levels of SIL-2R receptors in Type 1 upgrading reaction, both before and after treatment, as compared to all the other groups (with or without reactions). Interestingly, Tung et al. ${ }^{6}$ had highlighted similar findings earlier, in their maiden report. The apparent higher values in Type 1 upgrading reactions are not borne out by statistical analysis, due to large variation in individual SIL-2R readings relative to the sample sizes giving large standard deviation. However, it is tempting to speculate that the apparent difference of higher SIL-2R levels, between Type 1 upgrading reaction and other forms of reaction, is due to its unique immunopathogenesis.

SIL-2R values in the various test groups did not vary significantly from those obtained from the bacilliferous leprosy patients (without reaction), af ter detailed weighted analysis of the individual groups. BT patients (not having reaction) were all pauci bacillary and had significantly lower SIL-2R $(p<0.05)$. On pooling the data to form larger groups of patients with Type 1 (downgrading) or (upgrading), and Type 2 (ENL) reactions, Students' ' $t$ ' test revealed significantly higher levels of SIL-2R receptors in Type 1 upgrading reaction, both before and after treatment, as compared to all the other groups (with or without reactions). Interestingly, Tung et al. ${ }^{6}$ had highlighted similar findings earlier, in their maiden report. This apparently statistically significant, higher values, in Type 1 upgrading reactions, is not borne out on weighted analysis, due to large variations in individual SIL-2R readings, unique to this group, with respect to sample size (large standard deviation). However, it is tempting to speculate that the apparent difference of higher SIL-2R levels, between Type 1 upgrading reaction and other forms of reaction, is due to its unique immunopathogenesis.

The lack of significant differences in the test groups before and after treatment until clinical remission (some with corticosteroids) is intriguing, and is contrary to an earlier report of precipitous fall in SIL-2R levels following corticosteroid therapy. ${ }^{6}$ It would appear that SIL-2R levels remain unaffected by corticosteroids, even in Type 1 reactions, a finding identical to that of Scollard et al, ${ }^{25}$ in suction induced blisters, over representative skin lesions.

It is now known that SIL-2Rs are secreted in a wide variety of clinical and laboratory situations. ${ }^{1-3,5-7,20,22}$ Furthermore, all cells which manifest receptors for IL-2 are potential 
'secretors' of SIL-2R. ${ }^{19}$ Though SIL-2R binds IL-2 efficiently, this bindings is of low affinity and considerably high concentrations would be necessary for it to significantly block the action of IL-2, and cause down-regulation of IL-2 mediated responses. These levels are reportedly not obtained in vitro but may occur transiently in vivo, at least near the site of release. ${ }^{24}$ However, the contradictory finding of reduced SIL-2R after immunotherapy for allergy, ${ }^{26}$ may support the view that SIL-2Rs are a 'non-specific' secretory 'by-product' of intrinsic down-regulation by immunocompetent cells, following any alteration in a state of immunological 'balance'.'

In leprosy, reactions are an accepted manifestation of acute immunological imbalance', with changes in CD4 + cell activity and/or numbers. ${ }^{25}$ Raised SIL-2R values in reactions should then reflect the immunological instability. The lack of significant variation obtained perhaps underscores the inherent unstable immunity in patients manifesting leprosy per se. Further, the lack of change in SIL-2R levels following treatment and clinical subsidence of reaction points towards the absence of any role of SIL-2Rs in 'stabilizing' the immunological 'imbalance' that exists in these states.

\section{Ref erences}

1 Rubin LA, Kurman CC, Fritz ME, Biddison WE, Boutin B, Yarchoan R, Nelson DL. Soluble interleukin-2 receptors are released from activated human lymphoid cells in vitro. J Immunol, 1985; 135: 3172-7.

${ }^{2}$ Lotze MT, Custer MC, Sharrow SO, Rubin LA, Nelson DL, Rosenberg SA. In vivo administration of purified human interleukin-2 to patients with cancer: development of interleukin-2 receptor positive cells and circulating soluble interleukin-2 receptors following interleukin-2 administration. Cancer Res, 1987; 47: 2188-95.

3 Wagner DK, Kiwanuka J, Edwards BK, Rubin LA, Nelson DL, Magrath IT. Soluble interleukin-2 receptor levels in patients with undifferentiated and lymphoblastic lymphomas: correlation with survival. $J$ Clin Oncol, 1987; 5: 1262-74.

${ }^{4}$ Robb RJ, Kutny RM. Structure function relationship for the IL-2 receptor system: an analysis of the sequence and ligand binding properties of soluble Tac protein. J Immunol, 1987; 139: 855-62.

${ }_{5}^{5}$ Gupta S. Study of activated T cells in man. Clin Imm Immunopath, 1986; 38: 93-100.

6 Tung KSK, Umland E, Matzner P, Nelson K et al. soluble serum interleukin-2 receptor levels in leprosy patients. Clin exp Imm, 1987; 68: 10-15.

7 Ganguly NK, Vaishnavi C, Kaur S, Agnihotri N, Kumar B. Interleukin-2 receptors in sera of leprosy patients. Int J Lepr, 1989; 57: 870-2.

8 Ridley DS, Jopling WH. Classification of leprosy according to immunity. Int J Lepr, 1966; 34: $255-73$.

9 Sehgal VN, Koranne RV, Sehgal S, Beohar P, Sharma VK. Correlation of morphological, bacteriological, histopathological and immunological features of leprosy. J. Derm, 1985; 12: 243-50.

10 Sehgal VN. A seven group classification for institutional and field work. Lepr Rev, 1989; 60: 75.

11 Sehgal VN. Reactions in leprosy. Int J Derm, 1987; 26: 277-84.

12 Sehgal VN, Sharma V. Reactions in leprosy: a prospective study of clinical, bacteriological, immunological and histopathological parameters in thirty five Indians. J Derm, 1988; 15: 412-19.

13 Sehgal VN, Bhattacharya SN, Jain S. Relapse or late reversal? Int J Le pr, 1990; 58: 118-20.

14 WHO Expert Committee on Leprosy Sixth report. Technical Report Series No. 768, WHO: Geneva, 1988.

15 Christian M. Treatment and patient care. In: A guide to leprosy control, 2nd ed. WHO: Geneva, 1988. Pp. 30-46.

16 Welch BL. On the comparison of several mean values, an alternative approach. Biometrika, 1951; 38: 330-6.

17 Armitage P, Berry G. Multiple comparisons. In: Statistical method in medical research, 2nd ed. London: Blackwell Scientific Publication, 1987. Pp. 200-1.

18 Treiger BF, Leonard WJ, Svetlik P, Rubin LA, Nelson DL, Greene WC. A secreted form of the human interleukin-2 receptor encoded by an 'anchor minus' cDNA. J Immunol. 1986; 136: 4099-105.

19 Nelson DL, Rubin LA, Kurman CC, Fritz ME, Boutin B. An analysis of cellular requirements for the production of soluble interleukin-2 receptors in vitro. J Clin Immunol, 1986; 6: 114-20.

20 Wagner DK, York-Jolley J, Malek TR, Berzofsky JA, Nelson DL. Antigen-specific murine T cell clones produce soluble interleukin-2 receptor on stimulation with specific antigens. J. Immunol, 1988; 137: 592-6.

21 Cantrell DA, Collins MKL, Crumpton MJ. Autocrine regulation of T lymphocyte proliferation: differentiation induction of IL-2 and IL-2 receptor. Immunology, 1988; 65: 143-9. 
22 Loughnan MS, Sanderson CJ, Nossal CJV. Soluble interleukin-2 receptors are released from cell surface of normal murine B lymphocytes stimulated with interleukin-5. Proc Natl Acad Sci USA, 1988; 85: 3115-19.

2.3 Rubin LA, Jay G, Nelson DL. The released interleukin-2 receptor binds interleukin-2 efficiently. J. Immunol, 1986; 137: 3841-4.

24 Jacques Y, Le Mauff B, Boeffard F, Godard A, Soulillou J. A soluble interleukin-2 receptor produced by a normal alloreactive human T cell clone binds interleukin-2 with low affinity. J Immunol, 1987; 139: 2308-15.

25 Scollard DM, Suriyanon V, Bhoopat L et al. Studies of human leprosy lesions in situ using suction-induced blisters. 2. Cell changes and soluble interleukin-2 receptor (Tac Peptide) in reversal reactions. Int J Lepr, 1990; 58: 469-79.

${ }^{26}$ Hsieh K. Decreased production of interleukin-2 receptors after imunotherapy to house dust. J Clin Immunol, 1988; 8: 171-7.

\title{
Récepteurs solubles interleukine-2: les types de lèpre et les réactions pendant et après le type 1 (lepra) et le type 2 (ENL)
}

\author{
V N Sehgal, S N Bhattacharya, Y Shah, V K Sharma et \\ C K Gupta
}

Resumé Vingt-cinq patients présentant des réactions de type 1 (lepra) et de type 2 (ENL) firent l'objet d'un essai (SIL-2R dans du sérum) avant et après le traitement de leurs symptômes aigus et les résultats furent comparés avec ceux de 10 adultes sains normaux et 20 patients souffrant de lèpre per se. La classification de chaque sujet en différents groupes de lèpre et en différents types et sous-types de réactions fut fait selon des critères normaux avant le début de l'étude. Les évaluations statistiques détaillées des données révèlent des niveaux considérablement plus élevés de SIL-2R chez tous les lépreux comparés aux groupes témoins normaux, les groupes pluribacillaires ayant des niveaux plus élevés que les groupes paucibacillaires. Les récepteurs SIL 2Rs apparaissent en nombre plus élevé dans la réaction plus poussée de type 1 que dans les autres réactions quoique leur signification sur le plan statistique ne soit pas importante.

Les niveaux n'avaient pas fort changé à la suite d'un traitement ou d'une rémission clinique.

\section{Receptores solubles de interleucina-2: niveles en la lepra y, durante y después de las reacciones tipo 1 (lepra) y tipo 2 (ENL)}

\author{
V N Sehgal, S N Bhattacharya, Y Shah, V K Sharma Y \\ C K Gupta
}

Resumen Veinticinco pacientes con reacciones tipo 1 (lepra) y tipo 2 (ENL) fueron estudiados por SIL-2R en suero, antes y después del tratamiento de su condición aguda y los resultados se compararon con 10 adultos de salud normal y con 20 pacientes con lepra per se. Le classificación de cada sujeto en diferentes grupos de leprosos, y en varios tipos y subtipos de reacciones fue hecha de acuerdo a criterios estándar, previo a la inducción en el estudio. La evaluación estadística detallada de los datos reveló niveles elevados significativos de SIL-2R en todos los pacientes leprosos, comparados con los controles normales, con niveles más elevados en los grupos multibacilares comparado con el grupo paucibacilar. Los SIL-2R aparecieron más elevados en la reacción tipo 1 mejorada que en las otras formas de reacción, aunque esto no fue estadísticamente significativo.

No hubo cambios significativos en los niveles posteriormente al tratamiento y remisión clinica. 